\title{
Circular migration from the Eastern neighbourhood to the EU
}

Citation for published version (APA):

Vankova, Z. (2018). Circular migration from the Eastern neighbourhood to the EU: The rights of migrant workers in Bulgaria and Poland. [Doctoral Thesis, Maastricht University]. Wolf Legal Publishers (WLP). https://doi.org/10.26481/dis.20180627zv

Document status and date:

Published: 01/01/2018

DOI:

10.26481/dis.20180627zv

Document Version:

Publisher's PDF, also known as Version of record

\section{Please check the document version of this publication:}

- A submitted manuscript is the version of the article upon submission and before peer-review. There can be important differences between the submitted version and the official published version of record.

People interested in the research are advised to contact the author for the final version of the publication, or visit the DOI to the publisher's website.

- The final author version and the galley proof are versions of the publication after peer review.

- The final published version features the final layout of the paper including the volume, issue and page numbers.

Link to publication

\footnotetext{
General rights rights.

- You may freely distribute the URL identifying the publication in the public portal. please follow below link for the End User Agreement:

www.umlib.nl/taverne-license

Take down policy

If you believe that this document breaches copyright please contact us at:

repository@maastrichtuniversity.nl

providing details and we will investigate your claim.
}

Copyright and moral rights for the publications made accessible in the public portal are retained by the authors and/or other copyright owners and it is a condition of accessing publications that users recognise and abide by the legal requirements associated with these

- Users may download and print one copy of any publication from the public portal for the purpose of private study or research.

- You may not further distribute the material or use it for any profit-making activity or commercial gain

If the publication is distributed under the terms of Article $25 \mathrm{fa}$ of the Dutch Copyright Act, indicated by the "Taverne" license above, 


\section{Summary}

The policy idea of facilitating circular migration entered the EU's agenda more than a decade ago as part of a worldwide buzz among international organisations, namely that this type of migration could provide a "triple win solution" that would benefit all: the countries of origin and destination, as well as the migrant workers themselves. It is understood as a way of allowing migrants some degree of legal mobility back and forth between two countries. ${ }^{1}$ Despite the great policy and scholarly attention that has been paid to this concept, however, little is known about the implementation challenges of such policies and their consequences for the rights of migrant workers. The aim of this study is to contribute to filling this gap by assessing the implementation of EU policies and legal instruments that are designed to foster circular migration and how they affect migrant workers' rights in the context of circularity.

In order to answer the question of how the EU's circular migration approach has been implemented and what the consequences are for the rights of migrant workers, this $\mathrm{PhD}$ dissertation combines international, European and national law and implementation evaluation as part of an empirical legal research study. ${ }^{2}$ Tracing the implementation of the EU's approach to circular migration requires a three level analysis - policy formulation at the EU (and national) level, policy outputs developed at the EU and national level and policy outcomes measured at the individual level.

Addressing the need to examine the policy outputs developed at the EU and national level, this PhD study employs a comparative case study methodology. It focuses geographically on the Eastern neighbourhood, which comprises countries in Central and Eastern Europe (CEE) that attract migrant workers from the former Soviet Union republics. This region is an interesting case for research because it is understudied both in terms of issues related to legislation and policy of these new countries of immigration, as well as in terms of implementation of the EU's

1 European Commission, 'Communication on circular migration and mobility partnerships between the European Union and third countries', COM (2007) 248 final, Brussels, 16 May 2007, p. 8.

2 See F. L. Leeuw and H. Schmeets, Empirical Legal Research. A Guidance Book for Lawyers, Legislators and Regulators (Edward Elgar Publishing 2016), p. 6; p. 35. 
circular migration at the national level. Furthermore, the CEE currently comprises both EU and non-EU countries and is characterised by increasing cross-border migration, especially after the latest EU enlargement.

In order to be able to draw conclusions about the policy outcomes that arise from the implementation of the various migration instruments which fall under the circular migration umbrella at the national level, this $\mathrm{PhD}$ study applies legal empirical research methods, such as semi-structured interviews and focus groups. In this way, it highlights the consequences for the rights of migrant workers as a result of the application of different policy options.

The literature review conducted as part of Chapter 1 of this study reveals some of the key characteristics of circular migration: it is legal labour migration occurring through legal channels; it is repeated migration, involving more than one outward movement and return and it is temporary migration encompassing both temporary and long-term stays. Since the official discourse at the EU level is to foster this type of migration, this study tackles the key policy areas that must be addressed with this type of migration. It distinguishes between two types of policy areas: essential ones that enable migrants to circulate - such as entry and re-entry conditions, work authorisation and residence status, as well as the "circulation" of social security contributions; and secondary ones that can influence the willingness of migrants to engage in circular migration, namely the possibility for circular migrants to bring their family members with them during their periods of stay in the country of destination and to have their qualifications recognised. These are also policy areas that are considered to be problematic in terms of the previous experience with temporary (guest-worker) and circular migration policies (Chapter 2).

Chapter 3 develops a benchmark framework ${ }^{3}$ to assess whether these policy areas provide a "win" for the migrant worker within the context of the "triple win solution" that circular migration ostensibly offers. The premises thereof are firstly, whether the migrant has a certain degree of voluntarism and "free" movement or generally a free choice in the decision to migrate. This condition differentiates circular migration policies from general time-bound migration policies that are redolent of the guest-worker models. Secondly, what needs to be assessed is whether these policies provide adequate protection of the migrant workers' fundamental rights and rights that allow them to benefit from the circulation, such as

3 The English Oxford Dictionary defines "benchmark" as "a standard or point of reference against which things may be compared". 
the export of social security benefits when they return back home and provisions to ensure that their qualifications can be recognised.

In line with these premises, this chapter proposes a two-level benchmark framework for the assessment of circular migration policies. On the first level, standards developed at the international and at the European level in the field of human rights, migration, labour and social security law are identified as possible benchmarks in the study's key policy areas. Secondly, the proposed benchmark framework includes policy instruments that can help in the implementation of these benchmarks. They are identified as being conducive to circular migration management on the basis of a literature review of the lessons that have been learned from the application of similar time-bound labour migration policies, such as the experience with the guest-worker schemes, as well as good practices that have been identified from among the emerging new generation of circular migration programmes that were presented in Chapter 2.

This dissertation examines what has been achieved in relation to the two categories of circular labour migration which are relevant in the EU context: temporary engagement of EU settled third-country nationals returning to their countries of origin, and temporary opportunities for entry and re-entry for persons residing in a third country for the purposes of working in the EU. ${ }^{4}$ These two categories of circular migration are to be facilitated at the European level on the basis of a twofold approach. Firstly, the Commission planned to promote it on the basis of a legislative framework: by using existing legal migration instruments and introducing special measures in future legislative acts. This part of the approach to circular migration encompasses the sectorial legal migration framework that has already been promulgated at the EU level and which regulates the conditions of entry and residence for different categories of immigrants in line with the Blue Card Directive, ${ }^{5}$ the Seasonal Workers' Directive, ${ }^{6}$ the Single Permit Directive, ${ }^{7}$

4 European Commission, 'Communication on circular migration and mobility partnerships between the European Union and third countries', COM (2007) 248 final, Brussels, 16 May 2007, p. 8-9.

5 Council Directive 2009/50/EC of 25 May 2009 on the conditions of entry and residence of thirdcountry nationals for the purposes of highly qualified employment [2009] OJ L 155/17.

6 Directive 2014/36/EU of the European Parliament and of the Council of 26 February 2014 on the conditions of entry and stay of third-country nationals for the purpose of employment as seasonal workers [2014] OJ L 94.

7 Directive 2011/98/EU of the European Parliament and of the Council of 13 December 2011 on a single application procedure for a single permit for third-country nationals to reside and work in the territory of a Member State and on a common set of rights for third-country workers legally residing in a Member [2011] OJ L 343. 
the Intra-corporate Transferee's Directive, ${ }^{8}$ the Students' and Researchers' Directive, ${ }^{9}$ as well as the Long-term Residence Directive. ${ }^{10}$

Secondly, it has been incorporated as a policy instrument within the context of the Global Approach to Migration and Mobility (GAMM), which is the overarching framework for the EU external migration and asylum policy. The European Commission has planned to facilitate the development of circular migration schemes with third countries within the framework of the GAMM, which does not limit the spectrum of migrant categories that can participate in such initiatives. In order to analyse the whole spectrum of economically active migrants that can engage in circular migration, this dissertation focuses on both low-skilled (e.g., seasonal) and highly-skilled migrants (e.g., Blue Card holders, researchers, intra-corporate transferees), as well as migrants that possess a more permanent status which is commensurate with the aim of the European Commission to facilitate temporary engagement of EU settled third-country nationals returning to their countries of origin.

This study concludes that more than a decade after the EU policy makers adopted this concept, there is hardly a common approach to circular migration at the EU level. On the contrary, this is a policy notion that keeps straying in the EU Justice and Home Affairs domain and which finds a place in the Preambles of some of the legal migration directives and in the Mobility Partnerships' annexes, without having clear grasp of its meaning or tangible contours. This lack of a coherent formulation, as well as a common definition or a uniform understanding of what this policy term entails, leads to scattered outputs and an uneven implementation at the national level. ${ }^{11}$

This study demonstrates that two different concepts of circular migration can be discerned from the EU's approach. On the one hand, there is a spontaneous pattern of circularity that can be facilitated through a legislative framework, such

8 Council Directive 2003/109/EC of 25 November 2003 concerning the status of third-country nationals who are long-term residents [2003] OJ L 16.

9 Directive (EU) 2016/801 of the European Parliament and of the Council of 11 May 2016 on the conditions of entry and residence of third-country nationals for the purposes of research, studies, training, voluntary service, pupil exchange schemes or educational projects and au pairing [2016] OJ L 132.

10 Directive 2014/66/EU of the European Parliament and of the Council of 15 May 2014 on the conditions of entry and residence of third-country nationals in the framework of an intra-corporate transfer [2014] OJ L 157.

11 See also European Migration Network, 'Temporary and Circular Migration: empirical evidence, current policy practice and future options in EU Member States. Synthesis Report', (2011). 
as to a certain extent, in the context of the Blue Card Directive as well as in the Polish Oświadczenie procedure (see Chapter 6) that has been adopted under the auspices of the Eastern Partnership, and as a temporary migration scheme with a re-entry component that is regulated through the Seasonal Workers' Directive and some of the circular migration initiatives which are implemented under the Mobility Partnerships with the Eastern Partnership countries.

Furthermore, the incoherent formation of the EU's approach to circular migration reflects the emerging sectorial EU labour migration policy on the one hand, and the dynamics of the EU external migration policy under the aegis of the GAMM on the other. Therefore, coming back to the main research question of this study on how the EU's approach to circular migration has been implemented and whether it provides rights-based circularity for migrant workers in the Central and Eastern European context, the study shows that rights come at a certain "skill and qualifications" price in the EU. The four sectorial directives on labour migration that were analysed in Chapter 5 (Blue Card Directive, the Seasonal Workers' Directive, the Intra-corporate Transferee's Directive, and the Students' and Researchers' Directive) differentiate migrant workers on the basis of their skills and qualifications, as well as their attractiveness for the Member States' labour markets, and use these as the decisive features, on which the different statuses are assigned. ${ }^{12}$ The desired migrants at the EU level are the ones with higher qualifications because they are considered to contribute to the Member States and EU's economy the most. Blue Card holders are the only category that can benefit from rights-based circular migration that allows for a migrant-led trajectory. Despite that, the Blue Card Directive has hardly been used since it was adopted, due to the restrictive admission conditions, national parallel rules and the cumbersome implementation that has taken place in some Member States. As a result of this, the Blue Card Directive is currently pending a recast.

Circular migration as part of the GAMM is a vivid illustration of the desire of Member States to strictly adhere to their competence under Article 79 (5) TFEU. Therefore, this study reconfirms the assessments of other authors with regards to circular migration as part of the Mobility Partnerships: behind the façade of the Mobility Partnerships' annexes which contain reference to circular migration initiatives, there is nothing more than several small-scale projects and there

12 In this regard see B. Fridriksdottir, What Happened to Equality? The Construction of the Right to Equal Treatment of Third-Country Nationals in Europan Union Law on Labour Migration (PhD dissertation Radboud University Nijmegen, 2016); A. Wiesbrock, T. Jöst, and A. Desmond, 'Seasonal Workers Directive 2014/36/EU', in K. Hailbronner and D. Thym (eds.), EU Immigration and Asylum Law. A Commentary (Second Edition edn.: C. H. Beck/Hart/ Nomos 2016), p. 960. 
are only a few Member States that are eager to engage in this type of migration (Chapter 4). ${ }^{13}$ Apart from that, the only GAMM instrument that could currently make a difference for workers' rights is the Polish Oświadczenie procedure, which, as this study has demonstrated, is mainly used by the neighbouring countries of Poland (Chapter 6). The visa liberalisation with Georgia and Ukraine are other policy measures that can contribute to the initiation of individual circular migration projects.

The analysis of the implementation of the EU's approach to circular migration shows that it fails to accommodate the variety of activities and migrant profiles that can have circular migration trajectories, which require flexible solutions rather than temporary migration policies that make them go round in circles. This study shows that, with the exception of Blue Card holders, such flexible solutions are only available for migrants that possess a specific ethnic origin at the national level in the countries that were taken as case studies. Therefore, this study reconfirms the conclusions of other authors that circular migration, as a policy model, can provide for migrant-led trajectories and the protection of migrants' rights, only if it is perceived as a spontaneous pattern of migration, which is facilitated through the operation of flexible policies and a flexible legal framework (as in the case of Sweden ${ }^{14}$ and partially through the Oświadczenie procedure in Poland), rather than a temporary labour migration scheme, which is redolent of the guestworker model. ${ }^{15}$ This study concludes that the design of circular migration policies should take as their starting point, the existing spontaneous patterns of migration, such as the migration between Poland and Ukraine. ${ }^{16}$

An added value of this study is that it goes one step further and provides a comprehensive picture of the implementation dynamics of the EU's approach to circular migration at the national level by adding an empirical legal research dimension.

13 See S. Carrera and R. H. i. Sagrera, 'Mobility Partnerships: 'Insecurity partnerships' for Policy Coherence and Migrant Workers' Human Rights in the EU', in R. Kunz, S. Lavenex, and M. Panizzon (eds.), Multilayered Migration Governance: The Promise of a Partnership (Routledge, 2011). N. Reslow, 'Partnering for mobility? Three-level Games in EU External Migration Policy' (DPhil thesis, Maastricht University 2013); Nita, 'Circular Migration Within the EU-Moldova Mobility Partnership'.

14 This was extensively discussed in Chapters 2 and 4 respectively.

15 H. Schneider and A. Wiesbrock, 'Circular migration: A triple win situation? Wishful thinking or a serious option for suitable migration policy?', in D. Schiek, U. Liebert, and H. Schneider (eds.), European Economic and Social Constitutionalism after the Treaty of Lisbon (Cambridge: Cambridge University Press, 2011). R. Skeldon, 'Going Round in Circles: Circular Migration, Poverty Alleviation and Marginality', International Migration, 50/3 (2012).

16 On that, see also K. Newland, D. R. Mendoza, and A. Terrazas, 'Learning by Doing: Experiences of Circular Migration', Migration Policy Institute, Insight, September (2008). 
This study found that the results of the implementation of the EU instruments that fall under the circular migration umbrella on the rights of migrant workers is not straightforward and that it depends on various factors such as the national context, how the national migration policy has developed, the way in which EU law is transposed into domestic law and how Member States use their margin of appreciation. ${ }^{17}$

In the Polish context, the developed entry and re-entry facilitation instruments are compensatory measures that aim to restore the patterns of circular migration that were already in existence for decades (Chapter 6). All of the established national and EU instruments were part of a conscious policy choice to create facilitation for the citizens of the neighbouring CIS countries aligned with the country's foreign policy considerations. Therefore, the implementation of the EU and national instruments falling under the circular migration umbrella has provided these migrant workers in Poland with flexible possibilities for facilitated legal entry and re-entry into the country.

In the case of Bulgaria, where labour migration is regarded as something unwanted and as a temporary solution, the concept as such did not lead to the establishment of any new rights derived from national instruments in relation to entry and re-entry conditions (Chapter 7). Nonetheless, the different EU labour migration instruments and the visa facilitation agreements with Eastern Partnership countries have established certain rights, which need to be further developed and enforced by the different stakeholders: business organisations, NGOs and migrant workers. Currently, migrant workers cannot fully benefit from some of the rights introduced on the basis of EU law because of the fact that the directives have been cumbersomely and impractically transposed into domestic law, sometimes even in violation of EU law.

In the field of work authorisation, the EU law instruments falling under the circular migration umbrella have introduced rights for several categories of migrants with regards to the change of employer and the possibility to find alternative employment in case of unemployment. In the case of Poland, this is possible even when the EU acquis does not impose an obligation: under the general regime, which transposed the Single Permit Directive into Polish law. On the contrary, in the Bulgarian case these rights were established only for some categories of migrants as a result of the pressure to harmonise national law with EU requirements. There-

17 On that, see also C. Solé et al., Impact of Circular Migration on Human, Political and Civil Rights. A Global Perspective (Springer International Publishing, 2016). 
fore, in the Bulgarian case, the implementation of the EU's legal instruments has led to tangible results for the rights of migrant workers. Nevertheless, the implementation dynamics presented by this study suggest that due to the poor "quality" of the transposition of EU law, these rights cannot be easily enforced in practice, which renders them somewhat ineffective.

The results of this study show that applying the minimum standards under the EU Long-term Residence Directive with regards to allowed absences for circular migration facilitation is not a workable solution and an instrument that migrant workers actually prefer. Furthermore, in order to transit from permits allowing circulation to a more permanent status, migrants need to change their trajectories and plan their return to their countries of origin within the time limits specified by EU and national legislation. Therefore, with the exception of Blue Card holders who are granted flexible geographical mobility, the rest of the categories falling under the EU circular migration umbrella have not gained any additional rights, which in turn makes them more likely to circulate.

The policies on social security coordination and the recognition of qualifications for third-country nationals, who fall outside the scope of the EU acquis, are left to the Member States to determine. The analysis of these two policy fields shows that in cases where there are no EU acquis requirements to be implemented, Bulgaria and Poland have not been proactive due to the embryonic development of their migration policies, the lack of any demands at the political level to attract migrant workers and to create workable policies for their retention or circulation. Therefore, these policies are mainly driven by the notion to have some measures in place, rather than by incentives to create workable solutions, which would support a given policy: circular or not. Thus, they provide very limited rights to specific categories of migrants. Bulgaria sets a good example in this regard by pursuing an active policy for the negotiation of social security agreements on the basis of the GAMM framework. However, both countries fall short of investing in information campaigns and other measures that aim to raise awareness about these rights amongst migrant workers.

The implementation of the EU's family reunification policy at the national level provides for rights-based circular migration solutions only with regards to highly-skilled migrants, such as Blue Card holders, researchers and ICTs. For the rest of the migrant workers, these two policies are incompatible, unless migrant workers decide to change their migrant trajectory and settle in order to be able to satisfy the eligibility criteria for family reunification. The fact that the Family 
Reunification Directive allows Member States to impose addition conditions before authorising family reunification is another hindrance to family reunification for circular migrants that are not regarded as highly-skilled.

As Triandafyllidou stresses, on the ground circular migration is "shaped by labour market dynamics, and driven by the agency of the migrants", and this does not necessarily match the EU's approach. ${ }^{18}$ The analysis of the empirical data gathered through the conducted focus groups supports this conclusion by illustrating that migrants do not always follow the predetermined model of migration that is envisaged by policy makers. Despite the hurdles that must be overcome in order to find jobs and the restrictive policies concerning access to permanent residence or family reunification, migrant workers use their agency and rely on circumvention mechanisms, which allow them to continue with their own personal trajectories. In line with other authors' conclusions, ${ }^{19}$ the data analysis of this study suggests that flexible policies make migrants more prone to circulation and restrictive policies lead to settlement. Furthermore, in the case of Russian and Ukrainian migrants, factors such as the political situation in their countries of origin also contribute to changes in their migration trajectories and thus provide another argument for the development of rights-based labour migration policies that allow for flexibility, rather than circular migration policies.

Another important conclusion that is based on the current implementation study is that circular migration policies concern much more than just entry and re-entry conditions. The existing policies at both the EU and the national level that are labelled as circular migration measures currently place migrant workers in a more vulnerable position. In order to distinguish the policy concept of circular migration from the guest-worker models, policy makers need to consider adopting a rights-based approach that covers other policies that relate to circular migration, such as social security coordination and family reunification. Furthermore, the labour rights of such migrants need to be protected and enforced because of their vulnerable position. Even though this study did not focus on assessing the enforcement of these kinds of rights, they should nevertheless form part of any rights-based circular migration policy.

18 A. Triandafyllidou, 'Circular Migration at the Periphery of Europe: Choice, Opportunity, or Necessity?', in A. Triandafyllidou (ed.), Circular migration between Europe and its neighbourhood : choice or necessity? (Oxford: Oxford University Press, 2013).

19 See for instance D. S. Massey and K. A. Pren, 'Unintended consequences of US immigration policy: Explaining the post-1965 surge from Latin America', Population and Development Review, 38/1 (2012) 
To sum up, the answer to the research question of this study on how the EU's approach to circular migration is implemented and whether it provides rightsbased circularity for migrant workers in the Central and Eastern European context, is that the EU's approach has been driven by selectivity based on the skills and the qualifications of migrants and it only allows the most desirable migrants - the highly-qualified - with the possibility to engage in rights-based circular migration. However, the circular migration approaches at the national level differ between countries due to various factors such as the national context, stage of development of the national migration policy, the way in which EU law is transposed into domestic law and how Member States use their margin of appreciation. Consequently, this leads to different outcomes for the rights of migrant workers and very often to discrepancies between the predetermined models by policymakers and the migrants' realities. 